\title{
CHEMISTRY AND KARST
}

\author{
KEMIJA IN KRAS
}

\author{
William B. WHITE ${ }^{1}$
}

\begin{abstract}
William B. White: Chemistry and Karst

UDC 54:551.435.8

The processes of initiation and development of characteristic surface karst landforms and underground caves are nearly all chemical processes. This paper reviews the advances in understanding of karst chemistry over the past 60 years. The equilibrium chemistry of carbonate and sulfate dissolution and deposition is well established with accurate values for the necessary constants. The equations for bulk kinetics are known well enough for accurate modeling of speleogenetic processes but much is being learned about atomic scale mechanisms. The chemistry of karst waters, expressed as parameters such as total dissolved carbonates, saturation index, and equilibrium carbon dioxide pressure are useful tools for probing the internal characteristics of karst aquifers. Continuous records of chemical parameters (chemographs) taken from springs and other karst waters mapped onto discharge hydrographs reveal details of the internal flow system. The chemistry of speleothem deposition is well understood at the level of bulk processes but much has been learned of the surface chemistry on an atomic scale by use of the atomic force microscope. Least well understood is the chemistry of hypogenetic karst. The main chemical reactions are known but equilibrium modeling could be improved and reaction kinetics are largely unknown.

Keywords: Carbonate equilibrium, carbonate kinetics, karst denudation, hypogene chemistry, cave mineral deposition, calcite/aragonite problem.
\end{abstract}

Izvleček

William B. White: Kemija in kras

UDK 54:551.435.8

Procesi začetka in razvoja značilnih površinskih kraških oblik in podzemnih jam imajo skoraj vsi razlog v kemiji. Prispevek je pregled napredka v razumevanju kraške kemije v zadnjih 60 letih. Kemijsko ravnotežje raztapljanja in odlaganja karbonatov in sulfatov je dobro poznano, kjer natančno poznamo vse potrebne ravnotežne konstante. Tudi kinetika raztapljanja na makroskopski ravni je dovolj dobro poznana, da lahko modeliramo procese speleogeneze. Osnovne mehanizme raztapljanja na atomski ravni še vedno spoznavamo. Kemija kraških vodah, izražena v parametrih, kot so vsebnost raztopljenih karbonatov, indeks nasičenosti in ravnovesje tlaka ogljikovega dioksida, je danes uporabno orodje za raziskovanje značilnosti kraških vodonosnikov. Zvezno beleženje kemičnih parametrov na kraških izvirih in drugih kraških vodah (kemogrami) skupaj s pretočnimi hidrogrami razkrivajo podrobnosti o podzemnem sistemu pretakanja voda. Tudi kemizem odlaganja sige na makroskopski ravni dobro razumemo, raziskave $\mathrm{z}$ mikroskopi na atomsko silo (AFM) pa nam omogočajo nova spoznanja o procesih na atomski ravni. Še najmanj je razumljena kemija hipogenega krasa. Glavne reakcije so znane, vendar je že modeliranje ravnotežja pomanjkljivo, še manj pa vemo o kemijski kinetiki.

Ključne besede: ravnotežje karbonatov, karbonatna kinetika, kraška denudacija, hipogena kemija, jamsko mineralno odlaganje, problematika kalcit/aragonite.

\footnotetext{
${ }^{1}$ Department of Geosciences, The Pennsylvania State University, Deike Building, University Park, PA 16802, USA, e-mail: wbw2@psu.edu
}

Received/Prejeto: 02.03.2015 


\section{INTRODUCTION}

Preparing a review of chemistry and karst is somewhat of a challenge because to a large extent karst is chemistry. Karst landscapes are those in which removal of bedrock to form either surface or underground landforms is primarily by means of chemical dissolution and removal of rock mass in aqueous solution. In its most elementary form karst chemistry is described by three reactions:

For limestone

$\mathrm{CaCO}_{3}+\mathrm{CO}_{2}+\mathrm{H}_{2} \mathrm{O} \longleftrightarrow \mathrm{Ca}^{2+}+2 \mathrm{HCO}_{3}^{-}$

For dolomite (dolostone) $4 \mathrm{HCO}_{3}^{-}$

$\mathrm{CaMg}\left(\mathrm{CO}_{3}\right)_{2}+2 \mathrm{CO}_{2}+2 \mathrm{H}_{2} \mathrm{O} \rightarrow \mathrm{Ca}^{2+}+\mathrm{Mg}^{2+}+$

For gypsum

$\mathrm{CaSO}_{4} \cdot 2 \mathrm{H}_{2} \mathrm{O} \longleftrightarrow \mathrm{Ca}^{2+}+\mathrm{SO}_{4}^{2-}+2 \mathrm{H}_{2} \mathrm{O}$
The forward reactions describe the dissolution of the three main karstic rocks. The reverse reactions for limestone and gypsum describe the precipitation of calcite and gypsum speleothems. Dolomite does not, with few exceptions, precipitate directly from aqueous solutions in the cave environment. It is all very simple chemistry except for the details. This article is mainly a consideration of the details.

According to Shaw (1992) the role of carbon dioxide in speleothem deposition was first described by $\mathrm{Cu}$ vier in 1812 and by Silliman the elder in 1820. Carbonic acid as a dissolution agent came a bit later by Lyell in 1827 and by Imre Voss in 1821. The primary chemical mechanisms of cave development and of speleothem deposition were established well before the detailed investigations of cave and karst that began in the mid-1800s.

\section{THE PHYSICAL CHEMISTRY OF KARST}

\section{EQUILIBRIUM}

The calculation of calcite equilibrium solubility from thermodynamic quantities is made complicated by the fact that $\mathrm{H}_{2} \mathrm{CO}_{3}$ is a weak acid and thus only partially ionized. The basic system consists of these species: $\mathrm{CaCO}_{3}$ as a solid phase, a gas phase containing variable amounts of $\mathrm{CO}_{2}$, and an aqueous phase containing variable quantities of $\mathrm{Ca}^{2+}, \mathrm{H}_{2} \mathrm{CO}_{3}, \mathrm{HCO}_{3}^{-}, \mathrm{CO}_{3}^{2-}, \mathrm{H}^{+}$, and $\mathrm{OH}^{-}$. Six composition variables plus the partial pressure of $\mathrm{CO}_{2}$ in the gas phase require seven independent mathematical relationships for a complete solution. Equilibrium reactions between solid calcite and liquid, between gaseous $\mathrm{CO}_{2}$ and liquid, and between the aqueous species with each other provide five of these relationships and the requirement of charge balance among ionic species provides the sixth. The choices for the seventh constraint are (i) closed system - mass balance among carbon-bearing species, (ii) specification of $\mathrm{CO}_{2}$ pressure, and (iii) specification of $\mathrm{pH}$. Choice (ii) is usually the most helpful for the interpretation of karst processes.

This aspect of the physical chemistry of karst was well-established by the early $20^{\text {th }}$ Century, for example the monograph of Pia (1933) and the work of Henri Schoeller in the 1930s (see, e.g. Schoeller 1969). Calculations produced the well-known Trombe curves (Trombe 1952) widely used by karst geomorphologists to plot the supersaturation or agressivity of karst waters. Further refinements required taking account of the influence of other ions in solution, typically $\mathrm{Mg}^{2+}, \mathrm{Na}^{+}, \mathrm{SO}_{4}^{2-}, \mathrm{Cl}^{-}$, and $\mathrm{NO}_{3}^{-}$, the net effect of which was to modify the activities of the carbonate species. The effect of other ions is expressed as an activity coefficient, $\gamma$, for each carbonate species. For more detail see textbooks such as Drever (1997) or Langmuir (1997).

For a specified value of $\mathrm{CO}_{2}$ pressure, the equilibrium concentration of dissolved calcite and also the $\mathrm{pH}$ of the solution are fixed.

$$
\begin{aligned}
& m_{\mathrm{Ca}}=P_{\mathrm{CO}_{2}}^{\frac{1}{3}}\left[\frac{K_{1} K_{\mathrm{C}} K_{\mathrm{CO}_{2}}}{4 K_{2} \gamma_{\mathrm{Ca}} \gamma_{\mathrm{HCO}}^{2}}\right]^{\frac{1}{3}} \\
& p H=-\frac{2}{3} \log P_{\mathrm{CO}_{2}}-\frac{1}{3} \log \left|\frac{K_{1}^{2} K_{2} K_{\mathrm{CO}_{2}}^{2} \gamma_{\mathrm{Ca}}}{2 K_{\mathrm{C}} \gamma_{\mathrm{HCO}_{3}}}\right|
\end{aligned}
$$

In these equations, $\mathrm{m}_{\mathrm{Ca}}$ is the molal concentration of $\mathrm{Ca}^{2+}$, the $\gamma$ 's are the activity coefficients for $\mathrm{Ca}^{2+}$ and $\mathrm{HCO}_{3}^{-}, \mathrm{K}_{1}$ and $\mathrm{K}_{2}$ are the first and second dissociation constants for carbonic acid, $\mathrm{K}_{\mathrm{C}}$ is the solubility product constant for calcite, and $\mathrm{K}_{\mathrm{CO}_{2}}$ is the Henry's law constant for the solubility of $\mathrm{CO}_{2}$ in water. Equivalent equations can be written for the solubility of dolomite.

Using the equilibrium constants of Plummer and Busenberg (1982), the solubilities of calcite and dolomite can be calculated as a function of $\mathrm{CO}_{2}$ pressure (Fig. 1). Note that the equilibrium solubilities of calcite 


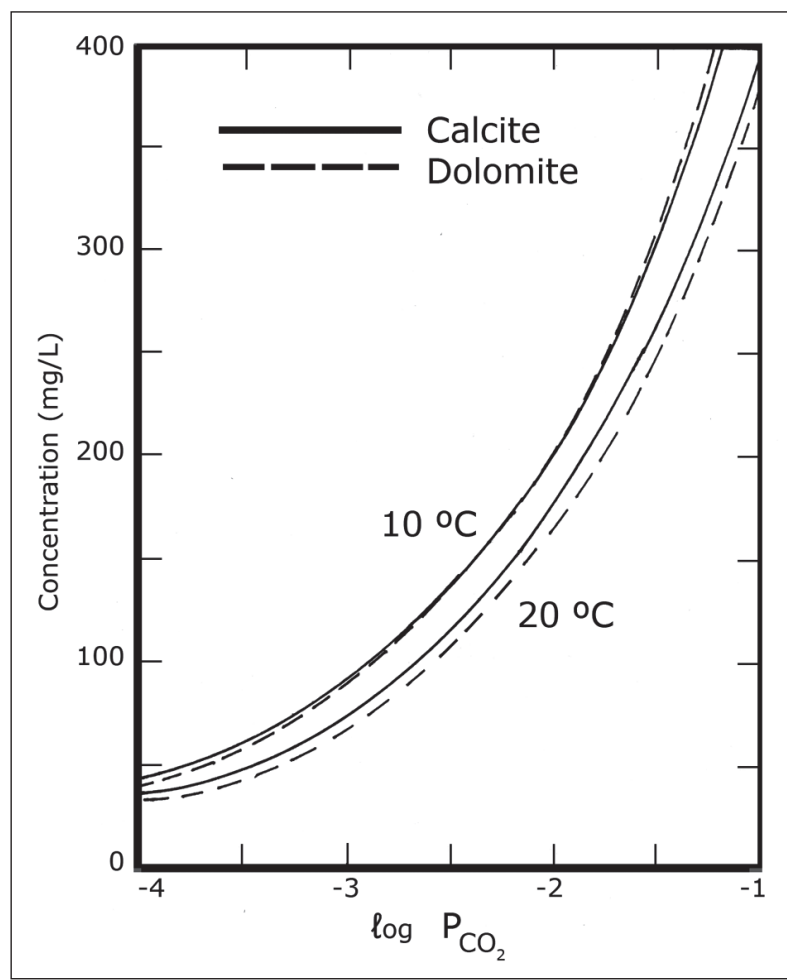

Fig. 1: Solubility curves for calcite and dolomite at 10 and $20^{\circ} \mathrm{C}$ as a function of $\mathrm{CO}_{2}$ pressure. The curves are calculated on an equimolar basis with dolomite written as $\mathrm{Ca}_{1 / 2} \mathrm{Mg}_{1 / 2} \mathrm{CO}_{3}$.

and dolomite are nearly equal when compared on an equimolar basis.

Further complications to the chemistry arise because of the formation of ion pairs such as $\mathrm{CaCO}_{3}^{0}$ and $\mathrm{CaHCO}_{3}^{+}$and complexes with other ions in the solution such as $\mathrm{MgHCO}_{3}^{+}$and $\mathrm{CaSO}_{4}^{0}$. Accurate calculations of solubility, saturation state, reaction progress and other variables are best done with a computer program such as the widely used PHREEQC program maintained by the U.S. Geological survey (Parkhurst and Appelo - see USGS Website).

Gypsum, the salt of a strong acid and a strong base, dissolves by simple ionic dissociation with no control by $\mathrm{pH}$ or $\mathrm{CO}_{2}$ pressure. The solubility does depend on temperature in a rather complex way (Fig. 2). At low temperature, the solubility increases with temperature, then reaches a broad maximum at about $38^{\circ} \mathrm{C}$ and then decreases at higher temperatures. At $58{ }^{\circ} \mathrm{C}$ gypsum looses its water of hydration to become anhydrite. The solubility curve (Fig. 2) was constructed from experimental data and seems to be more accurate than a curve calculated from thermodynamic data (Langmuir \& Melchoir 1985). Gypsum has about ten times the solubility of calcite but regardless, gypsum caves and gypsum karst have much the same morphology as limestone caves.

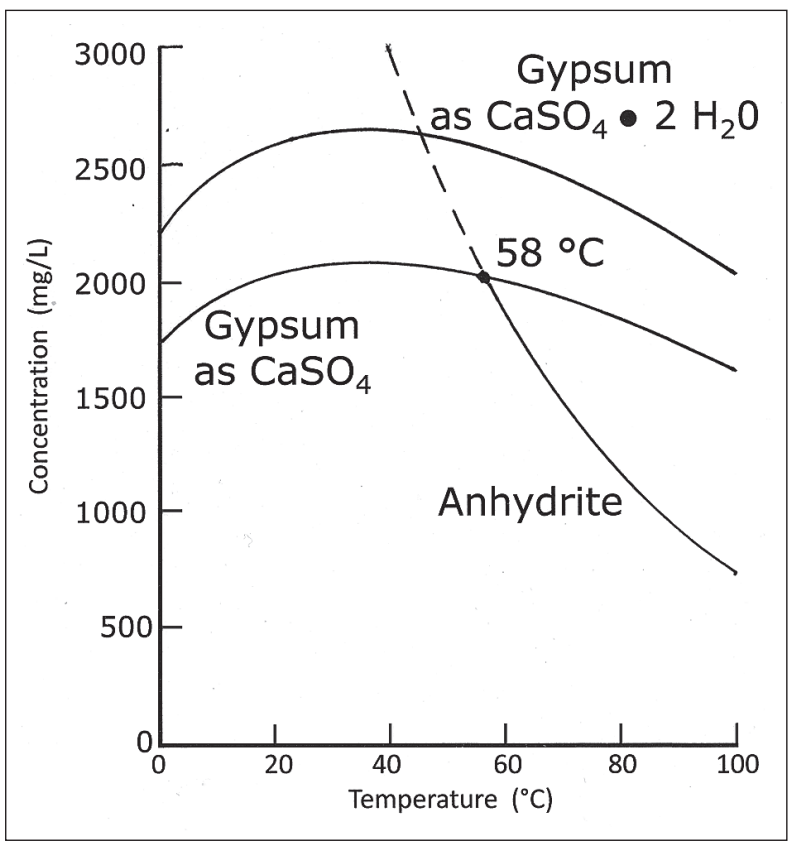

Fig. 2: Solubility of gypsum and anhydrite in the system $\mathrm{CaSO}_{4}-$ $\mathrm{H}_{2} \mathrm{O}$. Solubility curves calculated with the empirical equations of Blount \& Dickson (1973).

\section{KINETICS}

The dissolution of limestone is relatively slow, reactions requiring several days to reach equilibrium. In karst drainage systems water can move long distances in several days and thus the interpretation of cave and karst landform development is more a question of kinetics than of equilibrium. The dissolution and precipitation of carbonate minerals is of importance in oceanography, sedimentology, biomineralization, and in technological and medical applications. It is not surprising the calcite dissolution kinetics has accumulated a huge literature as shown in the reviews by Morse \& Arvidson (2002) and Morse et al. (2007).

It was early recognized that the rate of calcite dissolution falls into three distinct regimes depending on the undersaturation. At high undersaturations, $\mathrm{SI}_{\mathrm{C}}<-4$, the rate is proportional to hydrogen ion activity. At intermediate undersaturations, rate is a function of both undersaturation and $\mathrm{CO}_{2}$ partial pressure. Near saturation, $\mathrm{SI}_{\mathrm{C}}>-0.3$, the rate falls off by orders of magnitude as the solution approaches saturation. Attempts to represent this complex behavior have led to a variety of rate equations.

A widely used equation was developed by Plummer, Wigley and Parkhurst (1978).

$$
\text { Rate }=k_{1} a_{\mathrm{H}^{+}}+k_{2} a_{\mathrm{H}_{2} \mathrm{CO}_{3}}+k_{3} a_{\mathrm{H}_{2} \mathrm{O}}-k_{4} a_{\mathrm{Ca}^{2+}} a_{\mathrm{HCO}_{3}^{-}}
$$

The k-terms are rate constants which are temperature dependent. The a-terms are thermodynamic 
activities for the labeled species. The first term dominates in the high undersaturation regime. The high undersaturation regime cannot be achieved with carbonic acid but is appropriate for the dissolution of limestone in strong acids such as limestone barriers in acid mine streams. The intermediate undersaturation regime is described mainly by the first and second terms. In the near-saturation regime, the back-reaction term, $\mathrm{k}_{4}$, is responsible for the rapid drop-off in rate as the system approaches equilibrium.

Many variables have been investigated that impact the rate of calcite dissolution: fresh water vs seawater, saturation state of the fluid, impurities of various kinds, surface area and surface/volume ratios, and hydrodynamics of fluid motion. Usually the rate-controlling reaction is at the calcite surface but there are some circumstances where the rate at which dissolved $\mathrm{CO}_{2}$ reacts to form carbonic acid is important (Dreybrodt et al. 1996). The kinetics in the near-saturation regime are surface-reaction controlled and thus very sensitive to the presence of species adsorbed on the surface (Svensson \& Dreybrodt 1992; Eisenlohr et al. 1999) whereas the kinetics in the high-undersaturation regime are mass-transfer controlled and thus vary with the fluid flow rates (Kaufmann \& Dreybrodt 2007). Rather than the Plummer-WigleyParkhurst equation, many of these later investigations analyzed their data with some version of the basic rate equation (4).

$$
\text { Rate }=\frac{V d C}{A d t}=k\left(1-\frac{C}{C_{S}}\right)^{n}
$$

Rate is expressed as a direct function of the undersaturation. The key variable is the reaction order, n, which shifts from a value of 1 (first order kinetics) at high undersaturation to a value of 4 (fourth order kinetics) when $\mathrm{SI}_{\mathrm{C}}>-0.3$. Higher reaction orders have been observed. Palmer (1991) found this form of the rate equation useful for analyzing cave development and it has a mathematical form that adapts well to computer modeling of speleogenetic processes (Dreybrodt et al. 2005)

The dissolution kinetics of dolomite differs from the dissolution kinetics of calcite. At high undersaturation, dolomite dissolves at a rate similar to that of calcite up to a saturation index of about -2 . Instead of the curve continuing to rise to equilibrium, at about saturation in$\operatorname{dex}=-2$, the dolomite rate curve flattens so that times of weeks to months are needed for dolomite to eventually reach equilibrium (Fig. 3). Dolomite dissolves slowly at the undersaturation common to karst water and offers a chemical explanation for the observation that dissolutional landforms on dolomite are usually more subdued than those on limestone. Interest in the sequestration of carbon dioxide by deep burial has prompted investigations of the dissolution kinetics of carbonate minerals under a wider range of temperatures and pressures (Pokrovsky et al. 2005, 2009).

Gypsum is about ten times as soluble as calcite and has less complicated dissolution chemistry. A comprehensive experimental investigation (Raines \& Dewers 1997; commentary by Dreybrodt \& Gabrovšek 2000) suggests that under laminar flow conditions, the rate of gypsum dissolution is controlled by diffusion of ions across a boundary layer on the dissolving interface. The rate is determined by the thickness of the boundary layer which in turn is controlled by flow velocity across the surface. When velocities increase to the point where the flow becomes turbulent, control shifts to a surface reaction-controlled kinetics where the data were fitted to a second order rate law:

$$
\text { Rate }=k_{g y p}\left(1-\frac{C_{S}}{C_{e q}}\right)^{2}
$$

Further investigation and reinterpretation (Jeschke et al. 2001) suggests that dissolution of gypsum rock follows linear kinetics $(\mathrm{n}=1)$ at less than $60 \%$ saturation and fourth order kinetics $(n=4)$ closer to saturation. Chemically pure gypsum followed linear kinetics to equilibrium suggesting that impurities in rock gypsum were responsible for the decrease in dissolution rate near equilibrium. Whether the change in dissolutional mechanism with changing flow velocity can account for the very similar morphology of gypsum caves and gypsum karst does not seem to have been examined in detail.

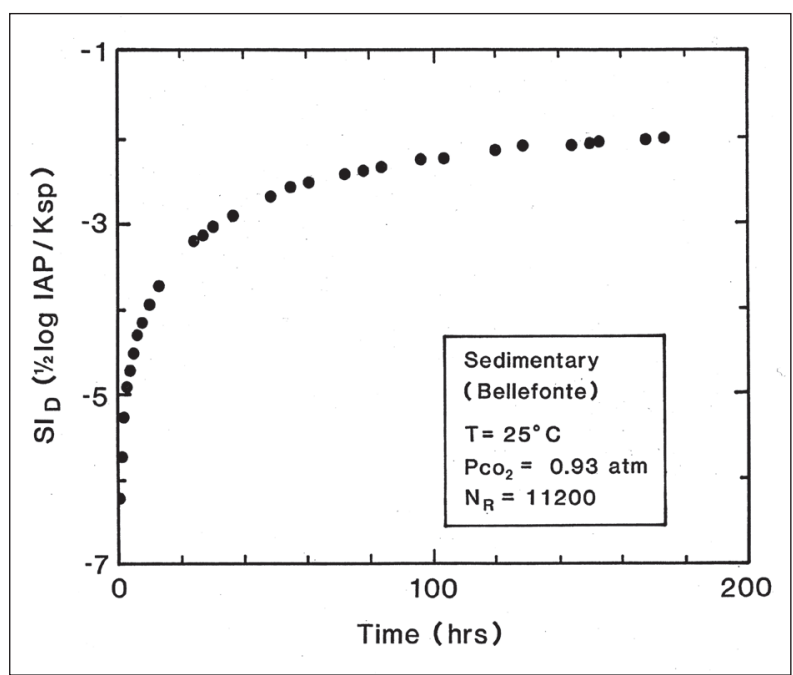

Fig. 3: Experimental rate curve for the dissolution of dolomite. The specimen was a disc of sedimentary dolomite spun in a solution at $25^{\circ} \mathrm{C}$, a fixed $\mathrm{CO}_{2}$ pressure of $0.93 \mathrm{~atm}$, and a Reynolds number of 11,200. From Herman \& White (1985). 


\section{GEOCHEMISTRY OF KARST WATERS}

Although the physical chemistry of karst waters as well as the chemistry of many other geologically important fluids was well-established by mid- $20^{\text {th }}$ Century, a subtle shift in paradigm occurred at about that time. Instead of sorting out the chemistry as an end in itself, the emphasis shifted to using the chemistry as a tool for interpreting geological processes. The primary instigator of the new aqueous geochemistry was Robert Garrels at Harvard University (Garrels \& Christ 1965). Garrel's student, Donald Langmuir introduced these new calculational techniques into karst hydrogeology (Langmuir 1971).

Before beginning an interpretation of karst water data it is important to have good data to begin with. There have been a number of publications describing analytical methods for water in general and karst water in particular (e.g. Krawczyk 1996). Good laboratory methods for cations and anions are required as are high quality field measurements of temperature, $\mathrm{pH}$, and specific conductance. However, rather than using the results of water analyses directly, they can be recombined into parameters that are more useful for hydrological interpretation.

The saturation index represents the ratio of ions actually present in solution to the concentration that would be present if the solution was in equilibrium.

$$
S I_{C}=\log \frac{I A P_{C}}{K_{C}}=\log \frac{\gamma_{\mathrm{Ca}} m_{\mathrm{Ca}} \gamma_{\mathrm{HCO}_{3}} m_{\mathrm{HCO}_{3}} K_{2}}{10^{-p H} K_{\mathrm{C}}}
$$

In this expression for the saturation index of calcite, IAP $_{C}$ is the ion activity product of $\mathrm{Ca}^{2+}$ and $\mathrm{CO}_{3}^{2-}$, the m's are molal concentrations, the $\gamma$ 's are activity coefficients, $\mathrm{K}_{2}$ is the second ionization constant of carbonic acid, and $\mathrm{K}_{\mathrm{C}}$ is the solubility product constant of calcite. Similar equations for saturation state can be written for other carbonate minerals.

The carbon dioxide partial pressure with which a karst water would be in equilibrium can also be calculated from the chemical analysis of the water.

$$
P_{\mathrm{CO}_{2}}=\frac{\gamma_{\mathrm{HCO}_{3}} m_{\mathrm{HCO}_{3}} 10^{-p H}}{K_{1} K_{\mathrm{CO}_{2}}}
$$

Equilibrium $\mathrm{CO}_{2}$ pressure and saturation index form useful plotting variables for describing karst waters and for mapping evolutionary pathways as the chemistry changes along the flow field. To these may be added some measure of the concentration of dissolved carbonates and the ratio of $\mathrm{Ca}^{2+}$ to $\mathrm{Mg}^{2+}$ ions in solution for a more complete description of karst waters.

An overview of karst water chemistry is displayed schematically in Fig. 4 using $\mathrm{SI}_{\mathrm{C}}$ and $\mathrm{P}_{\mathrm{CO}_{2}}$ as plotting variables. The soil is the primary source of $\mathrm{CO}_{2}$ but karst soils are usually strongly leached with very low carbonate content. Water percolating through the soil to the underlying epikarst is highly undersaturated. Reaction with carbonate rock in the epikarst brings the dissolved carbonate concentration and the saturation indices close to their equilibrium values and it is this water the drips from the ceilings of caves to deposit speleothems. Rapid $\mathrm{CO}_{2}$ loss to the cave atmosphere brings the drip waters to supersaturation. Cave streams feeding conduit-flow springs obtain their water from multiple sources including the epikarst, sinkhole drains, and sinking streams. They are typically undersaturated often near the transition value between fast first order kinetics and slow fourth order kinetics. The water draining from fracture springs have longer residence times and are typically closer to equilibrium with respect to the bedrock. Water moving through the vadose zone through open shafts, often as fast-moving streams and waterfalls is usually highly undersaturated but with $\mathrm{CO}_{2}$ partial pressures not much above the atmospheric background.

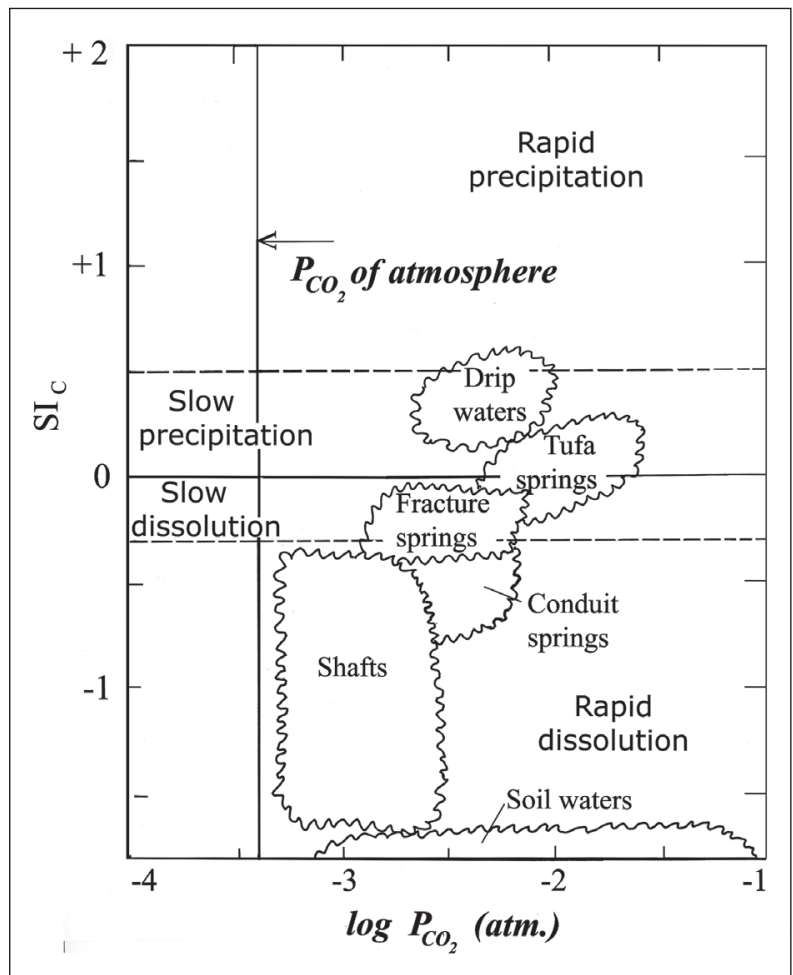

Fig. 4: Sketch showing the chemistry of various types of karst water mapped onto a plot of saturation index and $\mathrm{CO}_{2}$ partial pressure. The areas assigned to various water types are schematic only and indicate general trends. The lowest horizontal line represents the critical undersaturation of $S I_{C}=-0.3$ where the system shifts from $1^{\text {st }}$ order kinetics to $4^{\text {th }}$ order kinetics. The middle line represents equilibrium. The upper line represents the typical supersaturation, $S I_{C}=+0.5$, required for calcite nucleation and growth. 


\section{SPRING WATER CHEMISTRY}

\section{TIME SERIES}

The chemistry of water discharging from karst springs is time-dependent. Because of the rapid response of conduits to recharge from storms or snow melt, injected waters move through the system before they can come into chemical equilibrium with the wall rock. As a result, spring waters are often diluted by fresh storm water resulting in a substantial point to point variation in the concentration of dissolved carbonates. In temperate climates there is an additional influence due to the growing season. In the summer plant growth and other biological processes in the soil increase the $\mathrm{CO}_{2}$ partial pressure in the soil and the epikarst. The higher $\mathrm{CO}_{2}$ of the recharge water results in higher $\mathrm{CO}_{2}$ at the springs and possibly higher dissolved carbonate. These effects are illustrated with time series data from four springs:

- Penns Cave Rise (Centre County, Pennsylvania) is the outlet for a master conduit which receives about equal recharge from a karsted valley upland and from runoff from the bounding sandstone and shale mountains.

- Big Spring, (Bellefonte, Pennsylvania), is a large spring discharging from a fracture zone in dolomite. Its recharge area is unknown, but low $\mathrm{CO}_{2}$ pressures suggest an upland underlain by thin, organic-poor soils.

- Graham Spring, (Bowling Green, Kentucky) drains a large area of the Sinkhole Plain southeast of Mammoth Cave National Park.

- Rio Camuy Resurgence, (western Puerto Rico) is the outlet for the underground Rio Camuy which rises on the non-carbonate rocks of the central mountains, sinks at the limestone contact, and flows underground nearly $10 \mathrm{~km}$ to the resurgence.

Dissolved carbonate, sampled at roughly two-week intervals (Fig. 5) shows the expected pattern. The dissolved carbonate concentration in Big Spring, a fracture (or diffuse flow) spring is essentially constant throughout the year. The water is close to saturation but at a low $\mathrm{CO}_{2}$ partial pressure. The dissolved carbonate concentration in the other springs, all conduit springs, fluctuates from point to point as expected from the random introduction of storm runoff. Superimposed on the fluctuating concentrations are a distinct maximum in the late summer and early autumn for Penns Cave Rise and Graham spring. Both Pennsylvania and Kentucky have distinct growing seasons. In contrast, the dissolved carbonate concentration in Rio Camuy spring, in a tropical environment without distinct growing seasons, shows only the fluctuations due to storm inputs.

The carbon dioxide content of these spring waters is displayed as the ratio of the calculated equilibrium $\mathrm{CO}_{2}$ pressure in the water compared to the $\mathrm{CO}_{2}$ background in the atmosphere (Fig. 6). Because the $\mathrm{CO}_{2}$ content of the atmosphere has been rising continuously the comparison was made to the appropriate atmospheric $\mathrm{CO}_{2}$ at the time of sample collection. These values were $322 \mathrm{ppmV}$ in 1967 (Penns Cave and Big Spring), 328 ppmV in 1973 (Graham Spring) and 343 ppmV in 1983 (Rio Camuy). Most samples contained a $\mathrm{CO}_{2}$ concentration from ten to twenty times the atmospheric background. There is

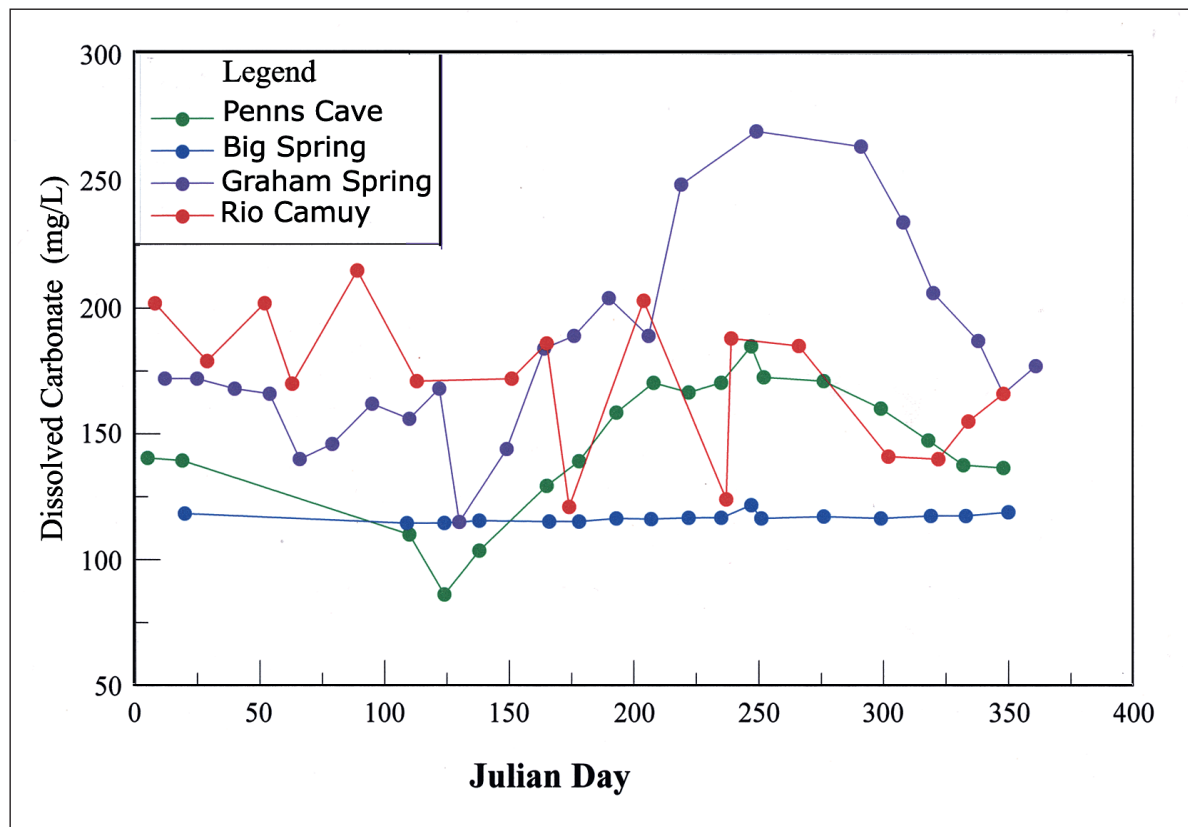

Fig. 5: Time series data for dissolved carbonate. The concentration is given as total dissolved carbonate calculated from measured concentrations of $\mathrm{Ca}^{2+}$ and $\mathrm{Mg}^{2+}$ as $\mathrm{CaCO}_{3}+\mathrm{MgCO}_{3}$. Source of data: Penns Cave Rising and Big Spring (Shuster 1970); Graham Spring (Hess 1974), and Rio Camuy (Troester 1994). 


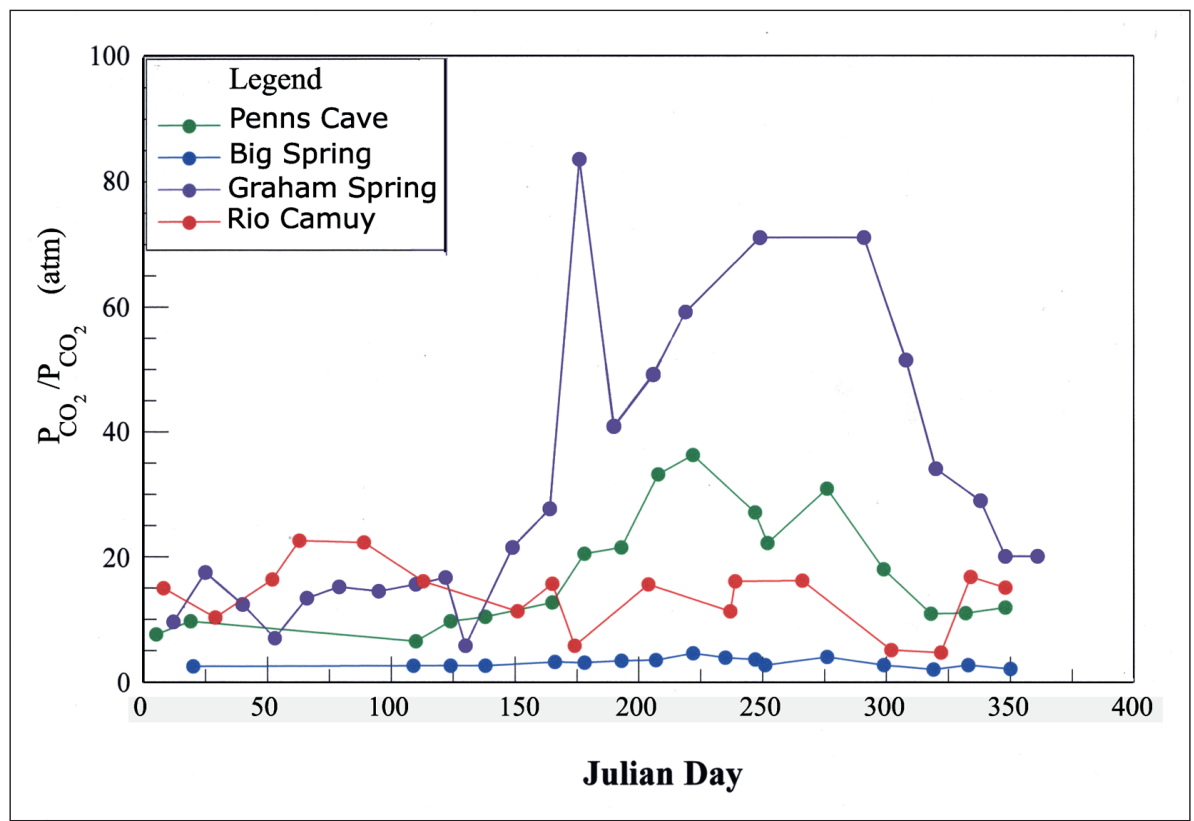

Fig. 6: Time series data for carbon dioxide. The $\mathrm{CO}_{2}$ content is expressed as an enhancement factor, the ratio of the calculated equilibrium $\mathrm{CO}_{2}$ partial pressure to the background $\mathrm{CO}_{2}$ pressure of the atmosphere. Data source same as in Fig. 5.

also the expected late summer to early autumn maxima in the two temperate climate conduit springs.

\section{CHEMOGRAPHS}

The data points collected in a time series study are, of course, only individual points on what must be a continuous variation of the concentration of the specified chemical species as a function of time. The complete curves are called chemographs and when superimposed on hydrographs provide much useful information on the internal behavior of karst aquifers. As noted by Dreiss (1989) for Maramec Spring in Missouri, individual storm peaks in the hydrographs have corresponding sharp dips in the chemographs. Most dissolved carbonate chemographs have been measured by continuously recording specific conductance which in turn is linearly proportional to the concentration of dissolved carbonates (Krawczyk \& Ford 2006).

The relationships between chemographs and hydrographs are most easily observed measuring both in response to a single intense storm that has been preceded by base flow conditions. Four common relationships are shown schematically in Fig. 7.

(i) Synchronous Response. Storm flow enters a karst aquifer from sinking streams and closed depressions, traverses the aquifer mainly as pipe or open channel flow through a conduit system, and reaches the spring, increasing the discharge to produce the rising limb of the hydrograph. Because the water emerging as the rising limb is storm water, the base flow concentration of dissolved carbonates, represented by high and constant specific conductance, is diluted and there is an abrupt drop in the specific conductance. As the storm flow recedes, the specific conductance gradually recovers to its prestorm value if it is not interrupted by a later storm. The recovery limb of the chemograph and the recession limb of the hydrograph generally do not coincide. The recovery limb of the chemograph often can be fitted to an equation of the form (Hess \& White 1988).

$$
S p c(\text { base flow })-S p c(t)=A e^{-b t}
$$

$A$ and $b$ are fitting parameters but $b$ has units of inverse time and can be regarded as a response time for the re-establishment of the base flow chemistry. Usually, different storms produce different recovery times. This can be due to different storm intensities and also to different

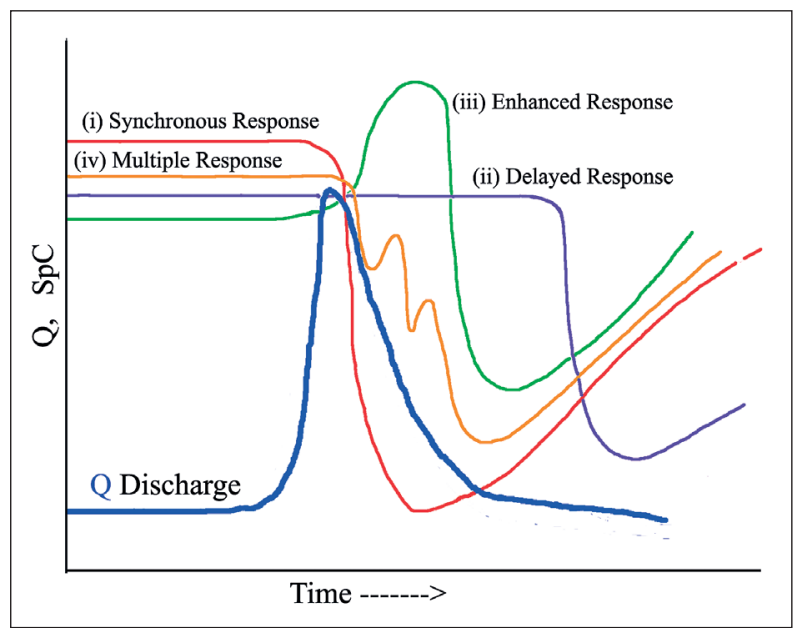

Fig. 7: Sketch showing various possible relations between chemographs of dissolved carbonate and the hydrograph of an isolated storm. See text for further discussion. 
storm tracks which changes the distribution of recharge to the aquifer. Likewise, the recovery time of the chemograph is not the same as the aquifer response time calculated from the hydrograph recession.

(ii) Delayed Response. The spring discharge rises sharply but the specific conductance remains constant for an additional period of hours or days and then falls. If the downstream portion of the conduit system lies below the spring orifice and is completely flooded, the arrival of storm recharge upstream raises the hydraulic head and forces an increased flow at the spring. The chemistry of the water being forced out of storage does not change immediately and only later does the actual storm water arrive at the spring. Measurement of the discharge and the time lag allows an estimate of the volume of water in the flooded section of the conduit (Ryan \& Meiman 1996).

(iii) Enhanced Response. In some chemographs, the specific conductance actually rises above base flow values in response to storm input before falling. An interpretation is that water with higher dissolved carbonate concentration is being forced out of fractures into the main conduit as a "first flush" to the spring before the storm flow arrives.

(iv) Multiple Response. The falling limb of the chemograph can be considered equivalent to the rising limb of the hydrograph, both abrupt responses to the arrival of a storm pulse at the measurement point in the spring. The falling limb of the chemograph is not always a smooth curve but instead sometimes shows a considerable amount of fine structure. The most obvious interpretation is that these secondary peaks and dips represent the arrival of water from different tributaries of the conduit system, each with a somewhat different chemistry. However, this attractive hypothesis has not been checked in detail nor has there been any interpretation of what, if anything, the chemograph reveals about the detail of the tributaries.

Specific conductance chemographs reveal that karst aquifer chemistry can change on very short time scales, sometimes a matter of minutes. High time-resolution produces more detail for interpretation. Chemographs can be constructed for any aqueous species including contaminants. The difficulty is the very large number of analyses that would be needed to produce useful time resolution (e.g. Liu et al. 2004). As an example, closely spaced analyses over the course of a storm pulse in a spring in western Kentucky showed that $\mathrm{CO}_{2}$ partial pressure increased sharply very close to the peak of the hydrograph (Vesper \& White 2004). This was interpreted as the arrival of storm water from the epikarst, lagging somewhat behind water that had entered the aquifer through sinking streams and closed depressions. In contrast to the specific conductance chemographs which dip in response to storm flow, total organic carbon peaked synchronously with the discharge hydrograph showing that this constituent is flushed out of the system during storm flow, rather than being diluted during storm flow.

\section{KARST DENUDATION}

The simplest possible application of chemistry to karst problems is what has been called "karst denudation". If the mass-wasting of carbonate rock is due primarily to transport of ions in solution, one can describe the mass loss as an average lowering of the entire land surface. Karst denudation can be measured directly on exposed rock surfaces by micrometer, by measuring weight loss of limestone tablets buried in the soil, and by measuring mass discharge of dissolved carbonates in the water exiting karst drainage basins. Interest in karst denudation arose from the extensive investigations of Jean Corbel (1957) who was seeking a climatic signal in denudation rates. Most of the early measurements were summarized by Smith and Atkinson (1976) and some later measurements by White (2007).

Most of the mass loss from carbonate rock dissolution takes place in the epikarst where highly acidic soil water meets the soil-carbonate rock interface. A maxi- mum denudation rate can be calculated if it is assumed that the reactions at the interface reach equilibrium.

$$
D_{n}=\frac{M_{c a l}}{\rho \sqrt[3]{4}}\left(\frac{K_{C} K_{1} K_{\mathrm{CO}_{2}}}{K_{2} \gamma_{\mathrm{Ca}} \gamma_{\mathrm{HCO}_{3}}^{2}}\right)^{\frac{1}{3}} P_{\mathrm{CO}_{2}}^{\frac{1}{3}}(P-E)
$$

In this equation, $\mathrm{D}_{\mathrm{n}}$ is denudation rate in $\mathrm{mm} / \mathrm{ka}$, $\mathrm{M}_{\text {cal }}$ is the molecular weight of $\mathrm{CaCO}_{3}$ (or a weighted average with $\mathrm{MgCO}_{3}$ in mixed rock types), and $\rho$ is the rock density in $\mathrm{g} \mathrm{cm}^{-3}$. (P-E), precipitation minus evapotranspiration, is the runoff expressed in mm/a. Denudation rate is proportional to runoff and varies with the cube root of the $\mathrm{CO}_{2}$ partial pressure. The temperature dependence is buried in the combined temperature dependences of the carbonate equilibrium constants. A more detailed model that takes account of the thickness of the active layer and the possibility that the reaction may not reach equilibrium is given by Gabrovšek (2007). 
Smith and Atkinson (1976) separated their collected denudation rate data into arctic, temperate, and tropical climates and fitted each set of data to a linear regression against runoff. By setting their regression coefficients equal to the coefficient of (P-E) in equation 9 and setting temperature equal to 0,10 , and $20^{\circ} \mathrm{C}$ for arctic, temper- ate, and tropical climates respectively, it was possible to calculate the corresponding $\mathrm{CO}_{2}$ pressures, the only unknowns in the equation. The calculated $\log \mathrm{P}_{\mathrm{CO} 2}$ of -3.07 , -2.31 , and -1.93 seem in very reasonable agreement with what might be expected for arctic, temperate and tropical climate regimes.

\section{MINERAL DEPOSITION AND MINERAL STABILITY}

Although the basic chemistry of calcite speleothem deposition has been known for more than a century, the additional details of the mechanism laid down by Holland et al. (1964) produced a model which has not been superseded. Rainwater, infiltrating through organic-rich soil, picks up a load of $\mathrm{CO}_{2}$ to a concentration that may reach one to ten volume percent. The highly undersaturated water reacts with the limestone or dolomite at the bedrock interface. The now nearly saturated water percolates downward through the vadose zone where a portion emerges as drip water from cave ceilings. The $\mathrm{CO}_{2}$ partial pressure of the drip water is much higher than the $\mathrm{CO}_{2}$ partial pressure of the cave atmosphere. $\mathrm{CO}_{2}$ is degassed, raising the saturation index past the critical supersaturation needed for calcite nucleation and speleothems are deposited. The balance between the growth of an existing calcite crystal and the nucleation of a new crystal is rather delicate. For this reason, caves with little evaporation or air circulation are often the sites for growth of large crystals of calcite (White 2012). Calcite deposited in caves with good air circulation or where drip water evaporates tends to be composed of small randomly-oriented crystals.

A major advance in understanding the surface chemistry of calcite growth has been the atomic force microscope. With the AFM it was possible to see the individual growth layers and measure the rate of growth on an atomic scale (Teng et al. 2000). Calcite grows on screw dislocations so that the growth steps are spirals winding around the dislocation axis. The AFM also permits observation of the effect of changing solution chemistry and the effect of impurities on growth rates and growth mechanisms (Larsen et al. 2010).

A long standing problem in cave mineral deposition is the common occurrence of aragonite. Aragonite is metastable with respect to calcite under cave ambient conditions and requires pressures in the range of 3000-5000 atmospheres to become thermodynamically stable. As a metastable phase, aragonite is more soluble than calcite but only about $10 \%$ more soluble (Fig. 8). The presence of $\mathrm{Sr}^{2+}$ ions produces aragonite-structure nuclei on which aragonite can grow epitaxially. The presence of $\mathrm{Mg}^{2+}$ ions poisons the growth steps on calcite, allowing the supersaturation to build up until it crosses the solubility curve for aragonite. With the atomic force microscope, the action of $\mathrm{Mg}^{2+}$ ions can be observed directly (Davis et al. 2000; Astilleros et al. 2010).

Gypsum speleothems occur widely in dry caves. Proposed sources for the gypsum include (i) re-working of primary gypsum interbedded in the limestone, (ii) oxidation of heavy metal sulfides, usually pyrite, $\mathrm{FeS}_{2}$, (iii) reaction products formed by reaction of sulfuric acid with the carbonate bedrock. Source (iii) is the result of

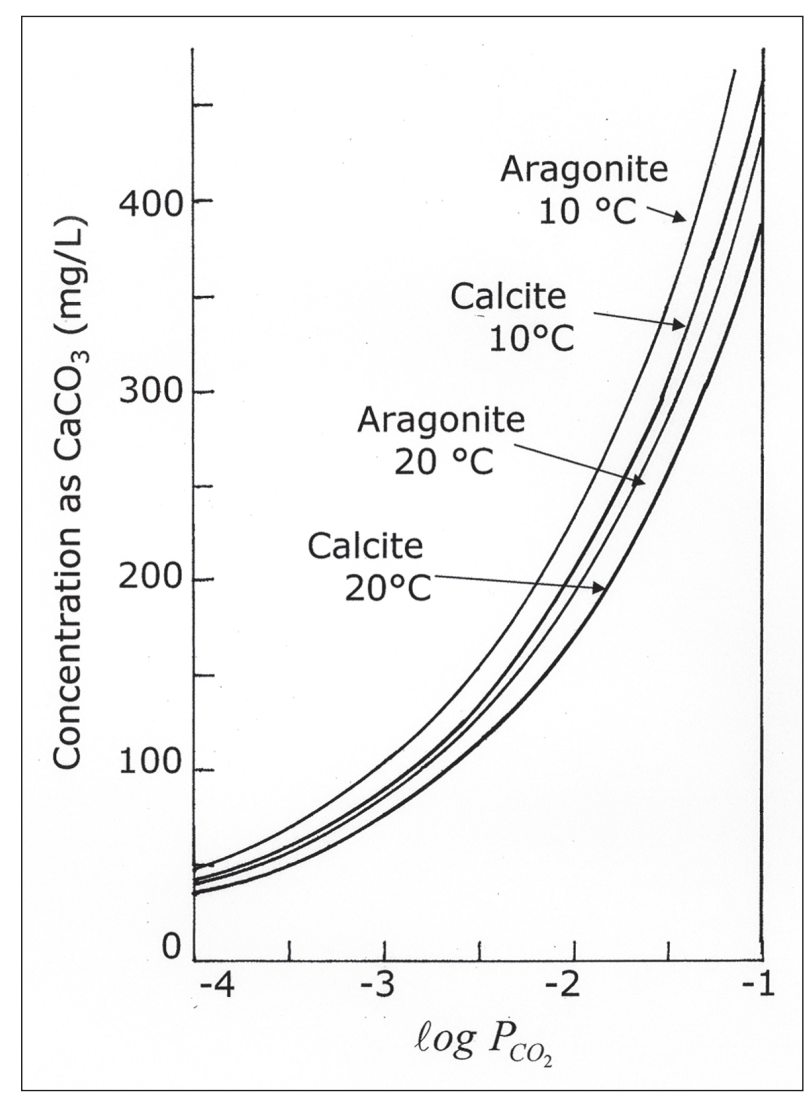

Fig. 8: Solubility curves for calcite and aragonite at 10 and $20^{\circ} \mathrm{C}$ as a function of $\mathrm{CO}_{2}$ partial pressure. 
the primary mechanism for the formation of hypogenetic caves. Indeed, the presence of massive gypsum deposits in Carlsbad Caverns and Lechuguilla Cave are essential evidence for the $\mathrm{H}_{2} \mathrm{~S}$ oxidation-sulfuric acid reaction mechanism for the formation of these caves. Source (ii) seems to be the most common but the details of the chemical mechanism by which pyrite is oxidized and the sulfate ions transported to be re-deposited as gypsum speleothems remain obscure. One mechanism would release $\mathrm{CO}_{2}$ to the cave atmosphere during gypsum speleothem growth, another requires the absorption of $\mathrm{CO}_{2}$ from the cave atmosphere during speleothem growth (White \& White 2003). An analysis of the fluid would resolve the issue but gypsum growth in dry caves does not involve measureable amounts of liquid water.

In addition to the commonly occurring calcite, gypsum, and aragonite, many other minerals have been precipitated in the cave environment (Hill \& Forti 1997). There are other carbonates and sulfates and there are minerals that involve redox reactions. The depositional chemistry can frequently be calculated from thermodynamic principles (White 1997).

\section{MIXING ZONE CHEMISTRY}

The equilibrium solubility of calcite varies with the cube root of the $\mathrm{CO}_{2}$ pressure (equation 1). Alfred Bögli noted (1964) that the non-linearity would mean that mixing water in equilibrium with limestone at high $\mathrm{P}_{\mathrm{CO}_{2}}$ with water at equilibrium with limestone at low $\mathrm{P}_{\mathrm{CO}_{2}}$ would produce a mixed water that would be undersaturated and could thus dissolve more limestone. Bögli developed the mechanism of mischungskorrosion as an explanation for cave origin near the water table as high- $\mathrm{CO}_{2}$ water from the epikarst met low- $\mathrm{CO}_{2}$ phreatic water. Mischungskorrosion features have been identified in caves but the overall importance of the mechanism to cave development seems less than originally proposed.

Examination of the detailed chemistry of mixed waters revealed other non-linearities that could result in a change in saturation index, either positive or negative (Wigley \& Plummer 1976). These are:

(i) Purely algebraic effects.

(ii) Redistribution of carbon-bearing species (the original mischungskorrosion).

(iii) The non-linear dependence of activity coefficients on ionic strength. (iv) Non-linear variation of equilibrium constants with temperature.

(v) Redistribution of ion pairs.

All of these effects enter the calculations so that an exact calculation of the saturation state of any mineral in any specific mixed water is best approached with a computer program such as PHREEQC. The ionic strength effect (iii) is most relevant to coastal karst.

Mixing of fresh water from interior aquifers with sea water in coastal zones produces mixed water that is sometimes undersaturated. Aggressive mixed waters were proposed as an explanation for the deep inlets (caletas) found along the east coast of the Yucatan Peninsula (Back et al. 1979) and are the accepted explanation for flank margin caves. The actual water chemistry varies with location and with detailed sampling sites. Undersaturated water was found on the coast of the Yucatan (Stoessell et al. 1989) and on Nauru Island (Jankowski \& Jacobson, 1991) but supersaturated water on the coast of Florida (Wicks et al. 1995).

\section{CHEMISTRY OF HYPOGENETIC KARST}

Hypogenetic or hydrothermal karst, mostly in the form of caves formed by waters rising from considerable depths usually at temperature well above surface ambients, is found in many regions (Goldscheider et al. 2010). There are two broad categories of hypogenetic karst processes - those that involve primary $\mathrm{CO}_{2}$ at high pressures and those that involve $\mathrm{H}_{2} \mathrm{~S}$ and its oxidation.
Carbon dioxide solubility decreases with temperature and increases with pressure (Portier \& Rochelle 2005). Calcite solubility also decreases with temperature (Fein \& Walther 1987). Calcite- and $\mathrm{CO}_{2}$ - charged water rising from depth along faults or fractures is both cooling along the geothermal gradient and also losing pressure. The result is that there is a deeper region where the rising solutions are undersaturated and can create caves 
and there is a higher zone (lower temperature and pressure) where the solutions become supersaturated and deposit calcite. Direct analysis of the primary fluids is rarely possible. The hydrothermal chemistry is deduced from the mineral deposits as in the example of the hydrothermal caves of Hungary (Dublyansky 1995)

The discovery of hypogene speleogenesis and certainly its importance in the development of such major caves as Carlsbad Caverns and Lechuguilla Cave must be taken as one of the most important advances in cave and karst studies over the past half century. Many efforts have been expended on the identification of characteristic morphological features and cave patterns that would indicate a hypogenetic origin (e.g Klimchouk \& Ford 2009). The chemistry has been written in broad brush terms but, because the hypogene solutions are not usually available, little detail is known. An essential component is a source of $\mathrm{H}_{2} \mathrm{~S}$. The $\mathrm{H}_{2} \mathrm{~S}$ source may be volcanic as in the example of Sistema Zacatón in Mexico (Gary 2010) or nearby petroleum fields in the example of the Guadalupe Mountain caves (Hill 1990).

For the specific case of $\mathrm{H}_{2} \mathrm{~S}$ derived from petroleum fields (Hill 1995), the following reactions can be written.

Stage 1. Creation of $\mathrm{H}_{2} \mathrm{~S}$ by hydrocarbon reduction of gypsum, probably mediated by microorganisms.

$$
\mathrm{CaSO}_{4} \cdot 2 \mathrm{H}_{2} \mathrm{O}+\mathrm{CH}_{4} \longleftrightarrow \mathrm{H}_{2} \mathrm{~S}+\mathrm{CaCO}_{3}+3 \mathrm{H}_{2} \mathrm{O}
$$

The reaction is written with solid gypsum as the initial reactant. Calcium carbonate is formed as one of the products. In reality, the reaction takes place in aqueous solution and the specific species depend on $\mathrm{pH}$ and $\mathrm{Eh}$ of the solution. $\mathrm{H}_{2} \mathrm{~S}$ in aqueous solution can migrate to regions where oxygen partial pressures are higher.

Stage 2. Deposition of elemental sulfur. Limited oxidation of $\mathrm{H}_{2} \mathrm{~S}$ produces elemental sulfur which is highly insoluble. Deposits of elemental sulfur are found around the Delaware Basin petroleum field and also in the Guadalupe cave deposits.

$$
\mathrm{H}_{2} \mathrm{~S}+1 / 2 \mathrm{O}_{2} \rightarrow \mathrm{S}^{\circ}+\mathrm{H}_{2} \mathrm{O}
$$

Hill (1995) gives a Stage 3 that involves metal-bearing solutions and the deposition of Mississippi Valley type metal sulfide ore deposits. This involves extraneous chemistry and need not be part of the general case.

Stage 4 and 5. Oxidation of $\mathrm{H}_{2} \mathrm{~S}$ and speleogenesis of hypogenetic caves. When deep-seated highly reducing solutions migrate upward to meet highly oxidizing ground water, the $\mathrm{H}_{2} \mathrm{~S}$ is oxidized to sulfuric acid and the sulfuric acid reacts with the surrounding carbonate rock.

$$
\begin{aligned}
& \mathrm{H}_{2} \mathrm{~S}+2 \mathrm{O}_{2} \longleftrightarrow 2 \mathrm{H}^{+}+\mathrm{SO}_{4}^{2-} \\
& 2 \mathrm{H}^{+}+\mathrm{SO}_{4}^{2-}+\mathrm{CaCO}_{3} \longleftrightarrow \mathrm{Ca}^{2+}+\mathrm{SO}_{4}^{2-}+\mathrm{H}_{2} \mathrm{O}+\mathrm{CO}_{2}
\end{aligned}
$$

The sulfate ion is carried on both sides of the equation to maintain charge balance. Most of the reaction products are carried off in solution leaving the cave opening behind. In the final stages, concentrations may exceed the solubility of gypsum in which case there is also a deposition reaction.

$$
\mathrm{Ca}^{2+}+\mathrm{SO}_{4}{ }^{2-}+2 \mathrm{H}_{2} \mathrm{O} \longleftrightarrow \mathrm{CaSO}_{4} \cdot 2 \mathrm{H}_{2} \mathrm{O}
$$

Details of speciation and concentrations depend on system variables such as temperature, total pressure, $\mathrm{pH}$, Eh and the concentration of other ions in solution.

More extensive speleogenetic modeling of hypogenetic caves requires more information on the chemistry of the deep-seated solutions which is difficult to obtain. Only at a few sites such as Cueva Villa Luz in Mexico are the active processes accessible for investigation (Hose et al. 2000).

\section{PROBLEMS FOR THE FUTURE}

It is probably fair to say that both equilibrium chemistry and chemical kinetics of the primary karstic minerals, calcite, aragonite, dolomite, and gypsum are reasonable well understood on the laboratory scale. Matters are less well-settled on the field scale. Problems for which future advances may be expected include the following.

The correlations between chemographs for various parameters and species and corresponding hydrographs are very helpful in the interpretation of aquifer behavior. The difficulty is in obtaining high density data along the time axis. The development of accurate, rugged, and reliable specific ion electrodes may be the answer.

There is a substantial discrepancy between calculated rates of cave development based on chemistry and the time scales determined by field observation and sediment dating. The explanation may be found in a study of dissolving surface. Surface chemistry on an atomic scale 
may add insight into the deposition of speleothems and their internal microstructure.

The role of microbial processes in all aspects of dissolution and deposition remains to be fully investigated.
Detail geochemical modeling of hypogene karst is an open problem. Ground truthing any proposed models may be challenging.

\section{REFERENCES}

Astilleros, J.M., Fernández-Diaz, L. \& A. Putnis, 2010: The role of magnesium in the growth of calcite: An AFM study.- Chemical Geology, 271, 52-58.

Back, W., Hanshaw, B.B., Pyle, T.E., Plummer, L.N. \& A.E. Weidie, 1979: Geochemical significance of groundwater discharge and carbonate solution to the formation of Caleta Xel Ha, Quintana Roo, Mexico.- Water Resources Research, 15, 1521-1535.

Blount, C.W. \& F.W. Dickson, 1973: Gypsum-anhydrite equilibria in systems $\mathrm{CaSO}_{4}-\mathrm{H}_{2} \mathrm{O}$ and $\mathrm{CaSO}_{4}-\mathrm{NaCl}-$ $\mathrm{H}_{2} \mathrm{O}$.- American Mineralogist, 58, 323-331.

Bögli, A., 1964: Mischungskorrosion - ein Beitrag zum Verkarstungsproblem.- Erdkunde, 18, 83-92.

Corbel, J., 1957: Les Karsts du Nord-Ouest de L'Europe et de Quelques Regions de Comparaison.- Institut des Études Rhodaniennes de L'Université de Lyon, Mémoires et Documents 12, 541 pp.

Davis, K.J., Dove, P.M. \& De Yoreo, J.J., 2000: The role of $\mathrm{Mg}^{2+}$ as an impurity in calcite growth.- Science, 290, 1134-1137.

Dreiss, S.J., 1989: Regional scale transport in a karst aquifer I. Component separation of spring flow hydrographs.- Water Resources Research, 25, 117-125.

Drever, J.I., 1997: The Geochemistry of Natural Waters.Prentice-Hall, pp. 436, Upper Saddle River, NJ.

Dreybrodt, W., Lauckner, J, Liu, Z., Svensson, U. \& D. Buhmann, 1996: The kinetics of the reaction $\mathrm{CO}_{2}+$ $\mathrm{H}_{2} \mathrm{O} \rightarrow \mathrm{H}^{+}+\mathrm{HCO}_{3}^{-}$as one of the rate limiting steps for the dissolution of calcite in the system $\mathrm{H}_{2} \mathrm{O}$ $\mathrm{CO}_{2}-\mathrm{CaCO}_{3}$.- Geochemica et Cosmochimica Acta, 60, 3375-3381.

Dreybrodt, W. \& F. Gabrovšek, 2000: Comments on: Mixed transport/reaction control of gypsum dissolution kinetics in aqueous solutions and initiation of gypsum karst by Michael A. Raines and Thomas A. Dewers in Chemical Geology 140, 29-48, 1997.Chemical Geology, 168, 169-172.

Dreybrodt, W., Gabrovšek, F. \& D. Romanov, 2005: Processes of speleogenesis: A modeling approach.- Carsologica, 4, 1-375.

Dublyansky, Y.V., 1995: Speleogenetic history of the Hungarian hydrothermal karst.- Environmental Geology, 25, 24035.
Eisenlohr, L., Meteva, K., Gabrovšek, F. \& W. Dreybrodt, 1999: The inhibiting action of intrinsic impurities in natural calcium carbonate minerals to their dissolution kinetics in aqueous $\mathrm{H}_{2} \mathrm{O}-\mathrm{CO}_{2}$ solutions.- Geochimica et Cosmochimica Acta, 63, 989-1002.

Fein, J.B. \& J.V. Walther, 1987: Calcite solubility in supercritical $\mathrm{CO}_{2}-\mathrm{H}_{2} \mathrm{O}$ fluids.- Geochimica et Cosmochimica Acta, 51, 1665-1673.

Gabrovšek, F., 2007: On denudation rates in karst.- Acta Carsologica, 36, 7-13.

Garrels, R.M. \& C.L. Christ, 1965: Solutions, Minerals, and Equilibria.- Harper \& Row, pp. 450, New York,

Gary, M.O., Karst hydrogeology and speleogenesis of Sistema Zacatón.- Association for Mexican Cave Studies Bulletin, 21, 1-114.

Goldscheider, N., Mádl-Szönyi, J., Eröss, A. \& E. Schill, 2010: Review: Thermal water resources in carbonate rock aquifers.- Hydrogeology Journal, 18, 1303-1318.

Herman, J.S. \& W.B. White, 1985: Dissolution kinetics of dolomite: Effects of lithology and fluid flow velocity.- Geochimica et Cosmochimica Acta, 49, 2017-2026.

Hess, J.W., 1974: Hydrochemical investigations of the central Kentucky karst aquifer system.- Ph.D. Thesis, The Pennsylvania State University, pp. 218.

Hess, J.W. \& W.B. White, 1988: Storm response of the karstic carbonate aquifer of southcentral Kentucky.Journal of Hydrology, 99, 235-252.

Hill, C. \& P. Forti, 1997: Cave Minerals of the World, $2^{\text {nd }}$ Edition.- National Speleological Society, pp. 463, Huntsville, AL.

Hill, C.A., 1990: Sulfuric acid speleogenesis of Carlsbad Cavern and its relationship to hydrocarbons, Delaware Basin, New Mexico and Texas.- American Association of Petroleum Geologists Bulletin, 74, 1685-1694.

Hill, C., 1995: Sulfur redox reactions: Hydrocarbons, native sulfur, Mississippi Valley-type deposits, and sulfuric acid karst in the Delaware Basin, New Mexico and Texas.- Environmental Geology 25, 16-23. 
Holland, H.D., Kirsipu, T.V., Huebner, J.S., \& U.M. Oxburgh, 1964: On some aspects of the chemical evolution of cave waters.- Journal of Geology, 72, 36-67.

Hose, L.D., Palmer, A.N., Palmer, M.V., Northup, D.E., Boston, P.J. \& H.R. DuChene, 2000: Microbiology and geochemistry in a hydrogen-sulphide-rich karst environment.- Chemical Geology, 169, 399-423.

Jankowski, J. \& G. Jacobson, 1991: Hydrochemistry of a groundwater-seawater mixing zone, Nauru Island, central Pacific Ocean.- Journal of Australian Geology and Geophysics, 12, 51-64.

Jeschko, A.A., Vosbeck, K. \& W. Dreybrodt, 2001: Surface-controlled dissolution rates of gypsum in aqueous solutions exhibit nonlinear dissolution kinetic.Geochimica et Cosmochimica Acta, 65, 27-34.

Kaufmann, G. \& W. Dreybrodt, 2007: Calcite dissolution kinetics in the system $\mathrm{CaCO}_{3}-\mathrm{H}_{2} \mathrm{O}-\mathrm{CO}_{2}$ at high undersaturation.- Geochimica et Cosmochimica Acta, 71, 1398-1410.

Klimchouk, A. \& D.C. Ford, 2009: Hypogene Speleogenesis and Karst Hydrogeology of Artesian Basins.Ukrainian Institute of Speleology and Karstology, pp. 292, Simferopol, Ukraine.

Krawczyk, W.E., 1996:- Manual for Karst Water Analysis.- International Journal of Speleology, Handbook I - Physical Speleology, pp. 50.

Krawczyk, W.E. \& D.C. Ford, 2006: Correlating specific conductivity with total hardness in limestone and dolomite karst waters.- Earth Surface Processes and Landforms, 31, 221-234.

Langmuir, D., 1971: The geochemistry of some carbonate ground waters in central Pennsylvania.- Geochimica et Cosmochimica Acta, 23, 1023-1045.

Langmuir, D. \& D. Melchior, 1985: The geochemistry of $\mathrm{Ca}, \mathrm{Sr}, \mathrm{Ba}$ and $\mathrm{Ra}$ sulfates in some deep brines from the Palo Duro Basin, Texas.- Geochimica et Cosmochimica Acta, 49, 2423-2432.

Langmuir, D., 1997: Aqueous Environmental Geochemistry.- Prentice-Hall, pp. 600, Upper Saddle River, NJ.

Larsen, K., Bechgaard, K. \& S.L.S. Stipp, 2010: The effect of $\mathrm{Ca}^{2+}$ to $\mathrm{CO}_{3}^{2-}$ activity ratio on spiral growth at the calcite $\{104\}$ surface.- Geochimica et Cosmochimica Acta, 74, 2099-2109.

Liu, Z., Groves, C., Yuan, D., Meiman, J. Jiang, G., He, S. \& Q. Li, 2004: Hydrochemical variations during flood pulses in the south-west China peak cluster karst: impacts of $\mathrm{CaCO}_{3}-\mathrm{H}_{2} \mathrm{O}-\mathrm{CO}_{2}$ interactions.Hydrological Processes, 18, 2423-2437.

Morse, J.W. \& R.S. Arvidson, 2002: The dissolution kinetics of major sedimentary carbonate minerals.Earth Science Reviews, 58, 51-84.
Morse, J.W., Arvidson, R.S. \& A. Lüttge, 2007: Calcium carbonate formation and dissolution.- Chemical Reviews, 107, 342-381.

Palmer, A.N., 1991: Origin and morphology of limestone caves.- Geological Society of America Bulletin, 103, $1-21$.

Pia, J., 1933: Die Theorien über die Löslichkeit des kohlensauren Kalkes.- Mitteilungen der Geologischen Gesellschaft in Wien, 25, 1-93.

Plummer, L.N., Wigley, T.M.L., \& D.L. Parkhurst, 1978: The kinetics of calcite dissolution in $\mathrm{CO}_{2}$-water systems at $5^{\circ}$ to $60{ }^{\circ} \mathrm{C}$ and 0.0 to 1.0 atm $\mathrm{CO}_{2}$.- American Journal of Science, 278, 179-216.

Plummer, L.N. \& E. Busenberg, 1982: The solubilities of calcite, aragonite, and vaterite in $\mathrm{CO}_{2}-\mathrm{H}_{2} \mathrm{O}$ solutions between 0 and $90{ }^{\circ} \mathrm{C}$, and an evaluation for the aqueous model for the system $\mathrm{CaCO}_{3}-\mathrm{CO}_{2}$ - $\mathrm{H}_{2}$ O.- Geochimica et Cosmochimica Acta, 46, 1011-1040.

Pokrovsky, O.S., Golubev, S.V. \& J. Schott, 2005: Dissolution kinetics of calcite, dolomite and magnesite at $25^{\circ} \mathrm{C}$ and 0 to 50 atm $p \mathrm{CO}_{2}$,- Chemical Geology, 217, 239-255.

Pokrovsky, O.S., Golubev, S.V., Schott, J. \& A. Castillo, 2009: Calcite, dolomite and magnesite dissolution kinetics in aqueous solutions at acid to circumneutral $\mathrm{pH}, 25$ to $150{ }^{\circ} \mathrm{C}$ and $1-55$ atm $p \mathrm{CO}_{2}$ : New constraints on $\mathrm{CO}_{2}$ sequestration in sedimentary basins.- Chemical Geology, 265, 20-32.

Portier, S. \& C. Rochelle, 2005: Modelling $\mathrm{CO}_{2}$ solubility in pure water and $\mathrm{NaCl}$-type waters from 0 to $300{ }^{\circ} \mathrm{C}$ and from 1 to 300 bar: Application to the Utsira Formation at Sleipner.- Chemical Geology, 217, 187-199.

Raines, M.A. \& T.A. Dewars, 1997: Mixed transport/ reaction control of gypsum dissolution kinetics in aqueous solutions and initiation of gypsum karst.Chemical Geology, 140, 29-48.

Ryan, M. \& J. Meiman, 1996: An examination of shortterm variations in water quality at a karst spring in Kentucky.- Ground Water 34, 23-30.

Schoeller, H., 1969: Lacide carbonique des eaux souterraines.- Bulletin du B.R.G.M, Section II, No. 1, $1-32$.

Shaw, T.R., 1992: History of Cave Science.- Sydney Speleological Society, pp. 338, Broadway, New South Wales, Australia.

Shuster, E.T., 1970: Seasonal variations in carbonate spring water chemistry related to ground water flow.- M.S. Thesis, The Pennsylvania State University, pp. 148. 
Smith, D.I. \& T.C. Atkinson, 1976: Process, landforms and climate in limestone regions.- In: Derbyshire, E. (ed.) Geomorphology and Climate. John Wiley \& Sons, pp. 367-409, London.

Stoessell, R.K., Ward, W.C., Ford, B.H. \& J.D. Schuffert, 1989: Water chemistry and $\mathrm{CaCO}_{3}$ dissolution in the saline part of an open-flow mixing zone, coastal Yucatan Peninsula, Mexico.- Geological Society of America Bulletin, 101, 159-169.

Svensson, U. \& W. Dreybrodt, 1992: Dissolution kinetics of natural calcite minerals in $\mathrm{CO}_{2}$-water systems approaching calcite equilibrium.- Chemical Geology, 100, 129-145.

Teng, H.H., Dove, P.M. \& J.J. De Yoreo, 2000: Kinetics of calcite growth: Surface processes and relationships to macroscopic rate laws.- Geochimica et Cosmochimica Acta, 64, 2255-2266.

Trombe, F., 1952: Traité de Spéléologie.- Payot, pp. 376, Paris.

Troester, J.W., 1994: The geochemistry, hydrogeology, and geomorphology of the Rio Camuy drainage basin, Puerto Rico: A humid tropical karst.- Ph.D. Thesis, The Pennsylvania State University, pp. 344.

Vesper, D.J. \& W.B. White, 2004: Storm pulse chemographs of saturation index and carbon dioxide pressure: implications for shifting recharge sources during storm events in the karst aquifer at Fort Campbell, Kentucky/Tennessee, USA.- Hydrogeology Journal, 12, 135-143.
White, W.B., 1997: Thermodynamic equilibrium, kinetics, activation barriers, and reaction mechanisms for chemical reaction in karst terrains.- Environmental Geology, 30, 46-58.

White, W.B. \& E.L. White, 2003: Gypsum wedging and cavern breakdown: Studies in the Mammoth Cave System, Kentucky.- Journal of Cave and Karst Studies, 65, 43-52.

White, W.B., 2007: Evolution and age relations of karst landscapes.- Acta Carsologica, 36, 45-52.

White, W.B., 2012: Speleothem microstructure/speleothem ontogeny: a review of Western contributions.- International Journal of Speleology, 41, 331-360.

Wicks, C.M., Herman, J.S., Randazzo, A.F. \& J.L. Jee, 1995: Water-rock interactions in a modern coastal mixing zone.- Geological Society of America Bulletin, 107, 1023-1032.

Wigley, T.M.L. \& L.N. Plummer, 1976: Mixing of carbonate waters. Geochimica et Cosmochimica Acta, 40, 989-995. 